\title{
Hepatoprotective Activity of Ethanol Extract of Figs Leaves (Ficus carica L.) with SGOT \& SGPT Parameters in Sprague Dawley Female Rats Induced by Paracetamol
}

\author{
(Efek Hepatoprotektif Ekstrak Etanol Daun Tin (Ficus carica L.) dengan Parameter \\ SGOT dan SGPT pada Tikus Betina Sprague Dawley yang Diinduksi Paracetamol)
}

\author{
Muhammad Fariez Kurniawan*, Herdita Nugraheny Kusuma Wardany \\ Program Studi Farmasi, Fakultas Kedokteran dan Ilmu Kesehatan, Universitas Muhammadiyah Yogyakarta, Yogyakarta, \\ Indonesia. \\ ${ }^{*}$ E-mail:fariez@umy.ac.id
}

Article Info:

Received: 23 January 2021

in revised form: 12 February 2021

Accepted: 13 July 2021

Available Online: 2 October 2021

\begin{tabular}{l} 
Keywords: \\
Figs Leaves \\
Hepatoprotective \\
Paracetamol \\
SGPT \\
SGOT \\
\hline Corresponding Author: \\
Muhammad Fariez Kurniawan \\
Program Studi Farmasi \\
Fakultas Kedokteran dan Ilmu \\
Kesehatan \\
Universitas Muhammadiyah \\
Yogyakarta \\
Yogyakarta \\
Indonesia \\
email: fariez@umy.ac.id
\end{tabular}

\section{ABSTRACT}

Background: Long-term usage of paracetamol damages liver cells characterized by the increasing levels of Serum Glutamic Pyruvic Transaminase (SGPT) and Serum Glutamic Oxaloacetic Transaminase (SGOT). Figs (Ficus carica L.) leaves contain high flavonoid compounds that able to act as hepatoprotector agents which inhibited the process of liver damage. Objectives: This study aims to determine the dose characteristics and hepatoprotective activity of figs (Ficus carica L.) leaves extract. Material and Methods: The hepatoprotective activity of figs extract (Ficus carica L.) was determined by measuring SGPT \& SGOT levels in rat blood. 42 rats were prepared, divided into 7 groups: normal control group, negative control given paracetamol with a dose $40 \mathrm{mg} / 200 \mathrm{~g} \mathrm{BW}$, positive control given hepamax ${ }^{\circledR}$, base control given $\mathrm{Na} \mathrm{CMC}$, and 3 test dose groups given figs leaves extract with a dose of $40 \mathrm{mg} / 200 \mathrm{~g} \mathrm{BW}, 80 \mathrm{mg} \mathrm{BW} / 200 \mathrm{~g} \mathrm{BW}$ and $160 \mathrm{mg} / 200 \mathrm{~g} \mathrm{BW}$. The treatment was carried out for 14 consecutive days. Paracetamol was given for 14 days, while positive control, 3 test dose groups and base control were given on day 7 to day 14. Rats blood samples were taken through the orbital sinuses on day 1 , day 5, day 10 and day 14 after treatment began. SGPT \& SGOT levels were determined using spectrophotometry with analytical methods using specific SGPT \& SGOT reagent kits. Results: The results showed that the leaves extract of figs (Ficus carica L.) proved to be able to reduce the levels of SGPT \& SGOT with the most potent dosage was $40 \mathrm{mg} / 200 \mathrm{~g} \mathrm{BW}$. However, the reduction of SGPT \& SGOT levels were not significantly different from other treatments. Conclusions: Figs (Ficus carica L.) leaves extract showed activity as a hepatoprotective agent, based on the reduction of SGPT \& SGOT levels in rat after 14 days of treatment.

Copyright $\odot 2019$ JFG-UNTAD

This open access article is distributed under a Creative Commons Attribution (CC-BY-NC-SA) 4.0 International license.

How to cite (APA $6^{\text {th }}$ Style):

Kurniawan, M. F., Wardany, H. N. K. (2021). Hepatoprotective Activity Ethanol Extract of Fig Leaves (Ficus carica L.) with SGOT \& SGPT Parameters in Sprague Dawley Female Rats Induced by Paracetamol. Jurnal Farmasi Galenika :Galenika Journal of Pharmacy (e-Journal), 7(2), 110-119. doi:10.22487/j24428744.2021.v7.i2.15433 


\begin{abstract}
ABSTRAK
Latar Belakang: Penggunaan parasetamol dalam jangka panjang merusak sel hati yang ditandai dengan peningkatan kadar Serum Glutamic Pyruvic Transaminase (SGPT) dan Serum Glutamic Oxaloacetic Transaminase (SGOT). Daun tin (Ficus carica L.) mengandung senyawa flavonoid tinggi dan diduga dapat berperan sebagai agen hepatoprotektor sehingga dapat menghambat proses kerusakan hati . Tujuan: Penelitian ini bertujuan untuk mengetahui karakteristik dosis dan aktivitas hepatoprotektif ekstrak daun tin (Ficus carica L.). Bahan dan Metode: Aktivitas hepatoprotektif ekstrak etanol daun tin (Ficus carica L.) ditentukan dengan mengukur kadar SGPT \& SGOT dalam darah tikus. Sebanyak 42 ekor tikus dibagi menjadi 7 kelompok yaitu kelompok kontrol normal, kontrol negatif yang diberi parasetamol, kontrol positif diberi hepamax ${ }^{\circledR}$, kontrol basis, dan 3 kelompok dosis uji yang diberi ekstrak etanol daun tin (Ficus carica L.) dengan dosis $40 \mathrm{mg} / 200 \mathrm{~g} \mathrm{BW}, 80$ $\mathrm{mg} / 200 \mathrm{~g}$ BW dan $160 \mathrm{mg} / 200 \mathrm{~g} \mathrm{BW}$. Perlakuan dilakukan selama 14 hari berturut-turut. Paracetamol diberikan selama 14 hari, sedangkan kontrol positif, kontrol dosis uji ekstrak Dan kontrol basis diberikan pada hari ke-7 sampai hari ke-14. Sampel darah tikus diambil melalui sinus orbital pada hari ke-1, hari ke-5, hari ke-10 dan hari ke-14 setelah perlakuan dimulai. Kadar SGPT \& SGOT ditentukan menggunakan spektrofotometri dengan metode analisis menggunakan reagen kit SGPT \& SGOT. Hasil: Hasil penelitian menunjukkan bahwa ekstrak daun tin (Ficus carica L.) terbukti mampu menurunkan kadar SGPT \& SGOT dengan dosis paling poten yaitu $40 \mathrm{mg} / 200$ g BW karena mempunyai kekuatan untuk menurunkan kadar SGPT \& SGOT yang tidak berbeda secara signifikan dari dosis $80 \mathrm{mg} / 200 \mathrm{~g} \mathrm{BW}$ dan $160 \mathrm{mg} / 200 \mathrm{~g} \mathrm{BW}$ tikus. Kesimpulan: ekstrak etanol daun tin (Ficus carica L.) menunjukkan aktivitas sebagai agen hepatoprotektif, karena dapat menurunkan kadar SGPT \& SGOT pada tikus setelah 14 hari perlakuan.
\end{abstract}

Kata kunci: Daun tin; Hepatoprotektor; Paracetamol, SGPT; SGOT

\title{
INTRODUCTION
}

Liver disease in Indonesia is considered the high category. One of the causes of liver disease is the use of hepatotoxic drugs. Hepatocytes (liver parenchyma cells) make up a large part of this organ. Hepatocytes are responsible for the central role of the liver in body metabolism. These cells are located between the sinusoids which contain blood and bile ducts (Corwin, 2010). The use of paracetamol as an analgesic and antipyretic has been widely known by the general public and is known as OTC drug. Inappropriate medication can result in an overdose of paracetamol which can lead to liver failure and then death within a few days. The toxic dose of paracetamol varies widely. In adults, hepatotoxicity occurs with a single dose of 10-15 grams (200-250 mg / kg) of paracetamol, doses of 20-25 g or more are likely to cause death. The general symptoms during the first day of acute paracetamol toxicity are not clearly visible. Events such as anorexia, nausea and vomiting and abdominal pain can occur within the first 24 hours and can last for several weeks. Liver disorders are estimated to occur on the second day, with symptoms, namely an increase in serum transaminase and lactate dehydrogenase activity and normal serum bilirubin levels (Katzung, 2010). The enzyme most often associated with hepatic cell damage is aminotransferase, which causes hepatic parenchymal cell damage to increase levels of Serum Glutamic Pyruvate Transaminase (SGPT) and Serum Glutamic Oxaloacetic Transaminase (SGOT) in plasma. SGPT is more specific than SGOT. SGPT is more in the myocardium than in hepatic cells, also SGOT is in striated muscles, kidneys, and brain (Bastiansyah, 2012). 
The fig (Ficus carica L.) plant comes from the Mediterranean. There have been many studies on the content and benefits of fig plants both leaves, fruit and roots, one of the benefits traditionally is that the leaves can be used to treat various diseases of the respiratory tract, cardiovascular, gastrointestinal tract and also as an antispasmodic and anti-inflammatory (Mawa et al, 2013). Flavonoid are the main compound in this plant and different extracts have been found have different biological activity (Gani et al, 2018). The main free flavonoid in fig leaves was found is luteolin, quercetin, and a free aglycone like methoxy-isoflavone and biochanin (Vaya, 2006). Quercetin is a group of flavonols, one of six subclasses of flavonoids containing high antioxidants that can be used as potent a chemopreventive and can be used to reduce growth of breast, lung, colon, and ovarian cancer cells (Sahoo et al, 2011). Bioavailability of quercetin is less than $17 \%$ in rats and $1 \%$ in humans (Kakran et al, 2011). Flavonoids, compounds known as antioxidants, reduce free radicals and inhibit the induction of inflammatory mediators that have the potential to cause damage to hepatocyte cells. The way it works is by increasing the activity of the enzyme catalase, superoxide dismutase, which is an endogenous antioxidant, and increasing the production of glutathione (GSH). Antioxidants namely vitamins A, C, and E can act as hepatoprotectors which may reduce oxidative stress by capturing electrophile structure compounds, namely paracetamol metabolites (NAPQI) which act as hepatotoxic so that they can cause liver damage (Wardah et al, 2016). The high flavonoid content in the leaves, researchers are very interested in exploring the benefits of fig leaves (Ficus carica L.) in Indonesia by conducting a phytochemical analysis of compounds from fig leaves (Ficus carica L.) and testing the hepatoprotector activity of fig leaves (Ficus carica L.) with SGOT \& SGPT parameters in female Sprague-Dawley rats induced with paracetamol.

\section{MATERIAL AND METHODS}

\section{Materials}

The materials used are distilled water, fig leaves purchased from Zam-Zam Therapy House, ethanol 70\% (Brataco), paracetamol 500 mg tablets (Kimia Farma), Hepamax ${ }^{\circledR}$, colloidal suspension Na-CMC $1 \% \mathrm{w} / \mathrm{v}$, Mayer's reagent, $1 \% \mathrm{FeCl} 3$, the mobile phase is a mixture of $\mathrm{n}$-butanol, acetic acid and water (technical grade), TLC plate silica gel Kiesegel 60 F254 0.25 mm (Merck), and Reigerd's SGPT \& SGOT reagent kit (Merck).

\section{Methods}

This research was conducted for approximately eight months in June 2019-February 2020 at the Pharmaceutical Technology Laboratory and Pharmacy Research Laboratory, Faculty of Medicine and Health Sciences, University of Muhammadiyah Yogyakarta. This study was approved by the UMY Ethics Committee Number 039/EP-FKIK-UMY//VI/2020. 


\section{Extraction}

The extract was prepared using the maceration method using $70 \%$ ethanol solvent for 5 days followed by remaceration for 2 days. Then phytochemical screening tests carried out included examination of alkaloids, tannins, saponins and flavonoids.

\section{Preparation of colloidal Na-CMC $1 \% \mathrm{w} / \mathrm{v}$}

$100 \mathrm{ml}$ of aquadest was heated at $70^{\circ} \mathrm{C}$. add 1 gram of Na-CMC gradually while stirring until a homogeneous colloid solution is formed. The dosage of test preparation given to experimental animals was $40 \mathrm{mg} / 200 \mathrm{~g} \mathrm{BW}, 80 \mathrm{mg} / 200 \mathrm{~g} \mathrm{BW}, 160 \mathrm{mg} / 200 \mathrm{~g} \mathrm{BW}$ which were given orally.

\section{Preparation of Test Animals}

In this study, 42 female white rats (Sprague dawley) weighing 150-200 g were used which were randomly divided into 7 treatment groups. The normal group is the group that is not given treatment. The negative group was given only Paracetamol $40 \mathrm{mg} / 200 \mathrm{~g} \mathrm{BW}$ of rats as toxic dosE the positive group was given Hepamax® (Syilimarin) at a dose of $20 \mathrm{mg} / \mathrm{g}$ BW of rats and the base group was given $1 \% \mathrm{Na}-\mathrm{CMC}$ as a control group. The treatment was carried out for 14 consecutive days. Paracetamol was given for 14 days, while positive control, base control and 3 test dose groups given figs extract (Ficus carica L.) with a dose of $40 \mathrm{mg} / 200 \mathrm{~g} \mathrm{BW}, 80 \mathrm{mg} / 200 \mathrm{~g} \mathrm{BW}$ and $160 \mathrm{mg} / 200 \mathrm{~g} \mathrm{BW}$ were given on day 7 to day 14 . Rats blood samples were taken through the orbital sinuses on day 1 , day 5 , day 10 and day 14 after treatment began. The first SGPT and SGOT enzyme values were measured before giving paracetamol and ethanol extract of fig leaves (Ficus carica L.). The aim was to determine the initial value of the SGPT and SGOT enzymes contained in rat blood serum so that these initial values could be compared with the values when given paracetamol and ethanol extract of fig leaves (Ficus carica L.).

\section{RESULTS AND DISCUSSION}

The plant determination showed that the fig leaves from the moraceae family were true Ficus carica $\mathrm{L}$. From the extraction process, 62.9 grams of thick extract of fig leaves were obtained so that the yield obtained was $12.58 \%$. Screening test for chemical compounds in fig leaves extract. The alkaloid content of fig leaves extract was tested by means of the extract being tested by adding a specific reagent, namely Mayer's reagent. The results obtained in this test are the negative ethanol extract of fig leaves containing alkaloid compounds without the formation of white deposits and only forming a precipitate. The principle of this analytical method is the precipitation reaction that occurs due to ligand replacement. The nitrogen atom which has the lone pair on the alkaloid can replace the iodo ion in the reagents. 
The Tannin test was carried out by adding the extract with $1 \% \mathrm{FeCl}_{3}$ solution drop by drop and the results obtained in the fig leaves extract formed a dark black color which indicated the formation of a complex compound between tannins and $\mathrm{Fe}_{3}{ }^{+}$which indicated a change in green, red, purple, blue or black color. Phytochemical test using $\mathrm{FeCl}_{3}$ is used to determine whether the sample contains phenol groups. The presence of phenol groups is indicated by a blackish green or dark blue color after adding $\mathrm{FeCl}_{3}$, so that it gives a positive result, it is possible that there are phenolic compounds in the sample and one of them is tannins because tannins are polyphenolic compounds. The classic way to detect simple phenolic compounds, namely adding extracts with $1 \% \mathrm{FeCl}_{3}$ solution in water, which causes a strong green, red, purple, blue or black color. The formation of a blackish green color in the extract after adding $\mathrm{FeCl}_{3}$ because tannins will form complex compounds with $\mathrm{Fe}_{3}{ }^{+}$ions (Harborne, 1987).

Forth test is performed to determine or identify saponin compounds. In the fig leaves extract that has been added with $5 \mathrm{~mL}$ of aqudest then shaken. The foam remains for 30 seconds so the identification shows the presence of saponins. This foam or foam indicates the presence of glycosides which have the ability to form foam in water which is hydrolyzed into glucose and other compounds (Marliana dkk, 2005).

Phytochemical screening tests were carried out to obtain information about the chemical content of fig leaves as a parameter of extract quality in relation to their pharmacological effects. The results obtained indicate that the fig leaves contain tannins, saponnins and flavonoids. Flavonoids, especially quercetin, are able to act as hepatoprotectors, thereby inhibiting the process of liver damage (Sawi and Sleem, 2010). The identification of quercetin compounds with TLC was carried out using the stationary phase silica gel plate (GF254). GF254 silica gel is a silica gel that is free from water and contains gypsum $\left(\mathrm{CaSO}_{4} \mathrm{H}_{2} \mathrm{O}\right)$ and compounds that fluoresce under UV254 light, but under UV366 light the plate will look dark. For the mobile phase used is ethyl acetate: methanol: water with a ratio (6.5: $2.85: 3)$. The result from TLC is shown in Figure 1.
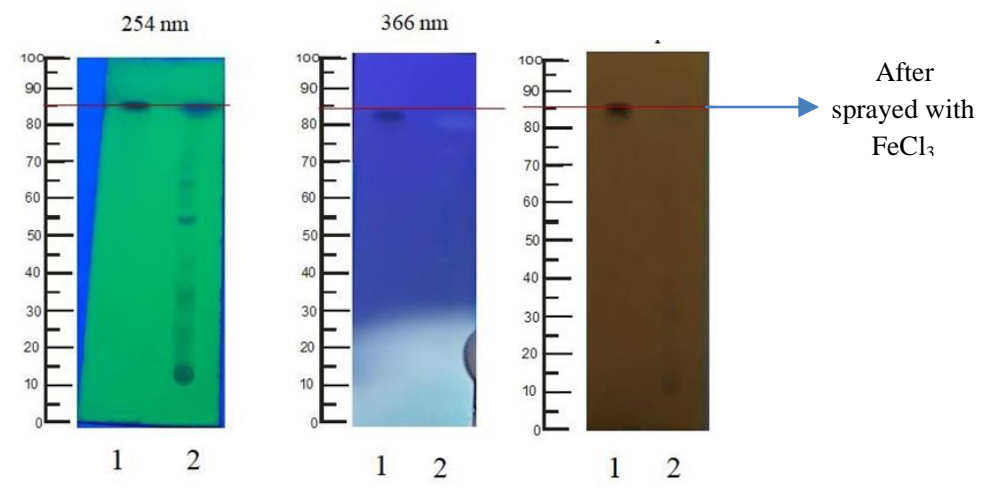

Figure 1. TLC Results of quercetin standar (1) and figs leaves extract (2) 
Table 1. Data from the observation of SGOT levels

\begin{tabular}{lllll}
\hline Group & $\begin{array}{c}\text { SGOT Blood } \\
\text { Levels } \\
(\text { IU/L) } \pm \text { SD } \\
(\text { day } \text { ) }\end{array}$ & $\begin{array}{c}\text { SGOT Blood } \\
\text { Levels } \\
(\text { IU/L) } \pm \text { SD } \\
(\text { day 5) }\end{array}$ & $\begin{array}{c}\text { SGOT Blood } \\
\text { Levels } \\
(\text { IU/L) } \pm \text { SD } \\
(\text { day 10) }\end{array}$ & $\begin{array}{c}\text { SGOT Blood } \\
\text { Levels } \\
(\text { IU/L) } \pm \text { SD } \\
(\text { day 14) }\end{array}$ \\
\hline Normal & $56.069 \pm 7.94$ & $56.06 \pm 7.94$ & $56.06 \pm 7.94$ & $56.06 \pm 7.06$ \\
\hline Negative & $64.66 \pm 6.42$ & $91.94 \pm 9.01$ & $87.22 \pm 3.19$ & $84.86 \pm 0.96$ \\
\hline Positive & $58.17 \pm 1.91$ & $87.15 \pm 3.61$ & $60.71 \pm 7.51$ & $63.56 \pm 12.37$ \\
\hline Base & $66.04 \pm 10.58$ & $88.48 \pm 5.84$ & $83.924 \pm 3.20$ & $84.91 \pm 2.77$ \\
\hline Dose I & $62.81 \pm 6.11$ & $91.40 \pm 10.36$ & $63.36 \pm 6.35$ & $58.93 \pm 5.95$ \\
\hline Dose II & $58.79 \pm 3.46$ & $88.65 \pm 3.71$ & $67.47 \pm 12.09$ & $54.81 \pm 6.52$ \\
\hline Dose III & $56.17 \pm 7.29$ & $85.85 \pm 1.95$ & $70.89 \pm 12.94$ & $52.14 \pm 4.95$
\end{tabular}

Table 2. Data from the observation of SGPT levels

\begin{tabular}{lcccc}
\hline \multicolumn{1}{c}{ Group } & $\begin{array}{c}\text { SGPT Blood } \\
\text { Levels } \\
(\mathbf{I U} / \mathbf{L}) \pm \text { SD } \\
(\text { day } \mathbf{)})\end{array}$ & $\begin{array}{c}\text { SGPT Blood } \\
\text { Levels } \\
\text { (IU/L) } \pm \text { SD } \\
(\text { day 5) }\end{array}$ & $\begin{array}{c}\text { SGPT Blood } \\
\text { Levels } \\
(\text { IU/L) } \pm \text { SD } \\
\text { (day 10) }\end{array}$ & $\begin{array}{c}\text { SGPT Blood } \\
\text { Levels } \\
\text { (IU/L) } \pm \text { SD } \\
\text { (day 14) }\end{array}$ \\
\hline Normal & $22.42 \pm 4.03$ & $21.53 \pm 4.64$ & $21.53 \pm 4.64$ & $21.53 \pm 2.14$ \\
\hline Positive & $23.84 \pm 0.81$ & $42.99 \pm 6.29$ & $50.83 \pm 3.09$ & $23.56 \pm 3.94$ \\
\hline Base & $19.99 \pm 1.69$ & $45.46 \pm 2.53$ & $47.11 \pm 4.35$ & $48 \pm 4.55$ \\
\hline Dose I & $22.66 \pm 2.45$ & $54.77 \pm 3.83$ & $40.84 \pm 2.91$ & $24 \pm 4.39$ \\
\hline Dose II & $22.05 \pm 1.14$ & $45.52 \pm 4.89$ & $44.74 \pm 1.35$ & $24.49 \pm 3.18$ \\
\hline Dose III & $19.51 \pm 1.01$ & $52.55 \pm 0.88$ & $51.69 \pm 3.21$ & $23.16 \pm 2.67$ \\
\hline
\end{tabular}

\section{SGOT Levels (IU/L)}

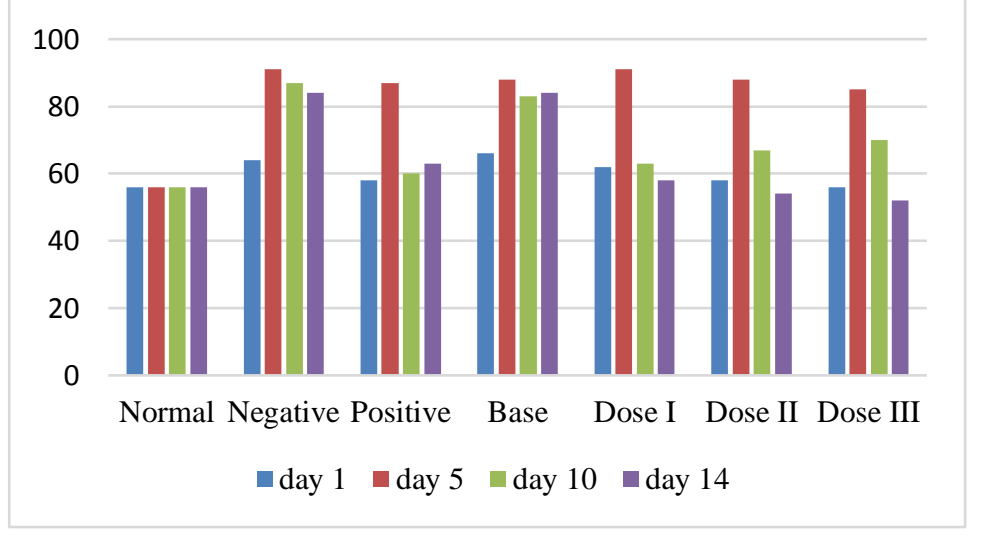

Figure 2. SGOT Blood Levels 


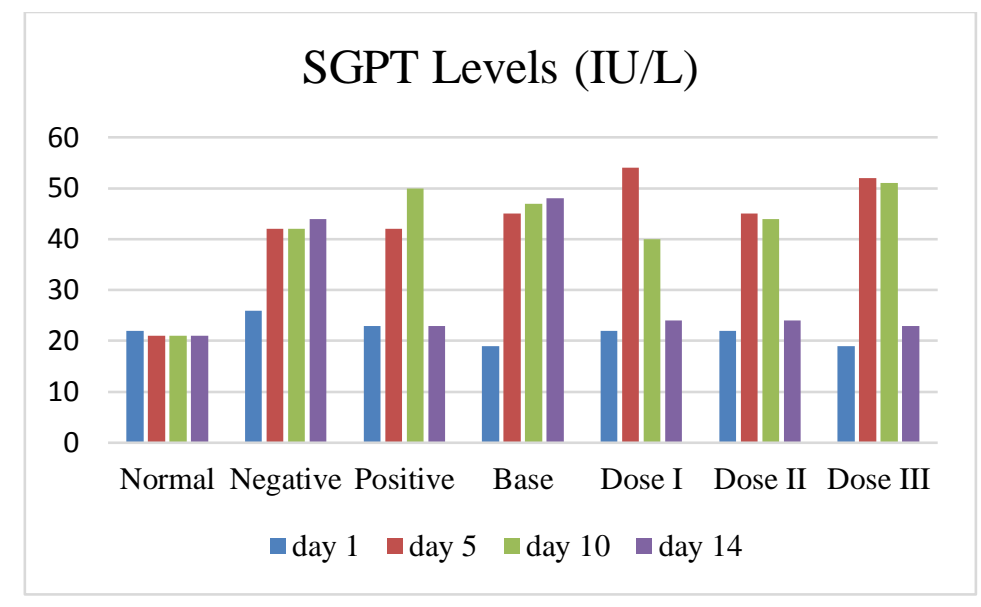

Figure 3. SGPT Blood Levels

Table 3. Results of One-way ANOVA Analysis

\begin{tabular}{lc}
\hline Groups & Statistical results $(\mathbf{p}<\mathbf{0 . 0 5})$ \\
\hline Negative vs Normal & 0.05 \\
\hline Negative vs Positive & 0.07 \\
\hline Positive vs Base & 0.07 \\
\hline Negative vs Dose I & 0.02 \\
\hline Negative vs Dose II & 0.01 \\
\hline Negative vs Dose III & 0.00 \\
\hline Dose I vs Dose II & 0.55 \\
\hline Dose I vs Dose III & 0.33 \\
\hline Dose II vs Dose III & 0.69
\end{tabular}

From the results of statistical tests using One-way ANOVA, the probability of both was less than 0.01 ( $\mathrm{p}<0.05$ ), which means that fig leaves extract (Ficus carica L.) with a gel base of Na-CMC had an effect on reducing SGPT and SGOT levels of Sprague dawley rats. To determine the significant effect between dose on the reduction of SGPT and SGOT levels, a further test was performed, namely the Least Significance Test (LSD). From the results of the LSD test, it was found that fig leaves extract based on $\mathrm{Na}-\mathrm{CMC}$ gel had a significant effect on reducing SGPT and SGOT levels because the probability of the LSD test results was less than $0.05(\mathrm{p}<0.05)$.

It can be seen in table 3 that the results of the analysis for the normal, negative, positive and basic groups did not show a significant difference because they did not meet the requirements $(\mathrm{p}<0.05)$. However, the negative group with test groups 1,2 and 3 showed a significant difference between groups of (p $<0.05$ ) so that there was a significant difference in the group given fig leaves ethanol extract (Ficus carica L.) and those that were not given that is the negative group.

In this study, paracetamol was used as an inducer of liver damage. If used above the treatment window it can result in liver damage. Paracetamol will form toxic reactive metabolites ( $\mathrm{N}$-acetyl-pbenzoquinone) and free radicals through the biotransformation process by the CYP450 enzyme with the 
help of CYP2EI isoenzymes. Reactive metabolites that are toxic and free radicals can interfere with the integrity of cell membranes and lead to liver damage. Giving paracetamol at a dose of $1000 \mathrm{mg} / \mathrm{kg}$ has been able to show liver damage which is characterized by increased levels of the SGPT enzyme (Abraham, 2005) (Roy and Das, 2010).

Liver damage mainly occurs in the centrolobular area because of the many cytochrome P450 enzymes there (Podolski and Isselbacher, 2002). Damage to the cell membrane causes the liver to secrete SGOT and SGPT enzymes. From the research conducted, it was found that the average SGPT level of the negative control group on the 14th day was $44.88 \pm 2.34 \mathrm{U} / \mathrm{L}$ and the average SGOT level results in the negative control group on the 14 th day was $84.86 \pm 0.96 \mathrm{U} / \mathrm{L}$. This shows that the paracetamol used as an inducer can cause liver damage, which shows the high levels of SGPT and SGPT in the negative control group given paracetamol compared to the SGOT and SGPT levels in the normal group. The mean SGOT levels in the dose group of $40 \mathrm{mg} / 200 \mathrm{~g} \mathrm{BW}, 80 \mathrm{mg} / 200 \mathrm{~g} \mathrm{BW}$, and $160 \mathrm{mg} / 200 \mathrm{~g} \mathrm{BW}$ rats respectively on day 14 were $58.93 \pm 5.95 \mathrm{U} / \mathrm{L}, 54.81 \pm 6.52 \mathrm{U} / \mathrm{L}, 52.14 \pm 4.95 \mathrm{U} / \mathrm{L}$. The mean SGPT levels in the dose group were $40 \mathrm{mg} / 200 \mathrm{~g} \mathrm{BW}, 80 \mathrm{mg} / 200 \mathrm{~g} \mathrm{BW}$, and $160 \mathrm{mg} / 200 \mathrm{~g} \mathrm{BW}$ of rats respectively on the 14th day, namely $24 \pm 4.39 \mathrm{U} / \mathrm{L}, 24.49 \pm 3,18 \mathrm{U} / \mathrm{L}, 23.16 \pm 2.67 \mathrm{U} / \mathrm{L}$. There was a decrease in SGOT and SGPT levels at each dose of fig leaves extract in the three dose test groups. This research simillar with the other study, that fig leaves extract in dose $200 \mathrm{mg} / \mathrm{kg}$ enhanced protection against $\mathrm{CCl}_{4}$ induced hepatic damage (Aghel et al, 2011). Methanolic extract of fig leaves with oral dose $500 \mathrm{mg} / \mathrm{kg}$ showed significant role as hepatoprotective activity in CCl4-induced liver damage in rat model by lowering alanine aminotransferase (SGPT), aspartate aminotransferase (SGOT), total serum bilirubin, and malondialdehyde (Krishna et al, 2007). It is indicated promising hepatoprotective activity that shown form in vitro test (Badgujar et al, 2014).

In the comparison of levels shown in Tables 1,2,3 and figures 2 and 3. There was a decrease in the levels of the SGPT and SGOT enzymes from the three doses, but these decreases did not show a significant difference etween the three doses. At a dose of $40 \mathrm{mg} / 200 \mathrm{~g} \mathrm{BW}$, rats had shown a decrease in SGPT \& SGOT levels in serum, although the two levels, $80 \mathrm{mg} / 200 \mathrm{~g} \mathrm{BW}$ and $160 \mathrm{mg} / 200 \mathrm{~g} \mathrm{BW}$ of rats, also met the normal levels of SGPT and SGOT.

\section{CONCLUSION}

The ethanol extract of fig leaves (Ficus carica L.) contains a flavonoid which is thought to be quercetin, which is a potential hepatoprotective agent. In the analysis, the results showed that there was no significant difference in the value reduction in SGPT and SGOT levels between doses, and the dose of $40 \mathrm{mg} / 200 \mathrm{~g} \mathrm{BW}$ is the most effective dose which has properties as a hepatoprotective agent. 


\section{ACKNOWLEDGEMENT}

Authors acknowledge LP3M Universitas Muhammadiyah Yogyakarta for financial support by Grant Research 2020.

\section{CONFLICT OF INTEREST}

Authors declare that there is no conflict of interest

\section{REFERENCES}

Abraham, P, (2005). Oxidative stress in paracetamol-induced pathogenesis: (I) renal damage. Indian J Biochem Biophys, 42(1):59-62. PMID: 23923583

Aghel, N., Kalantari, H., Rezazadeh, S. (2011). Hepatoprotective Effect of Ficus carica Leaf Extract on RatsIntoxicated with Carbon Tetrachloride. Iran J Pharm Res.10(1):63-8. PMID: 24363682; PMCID: PMC3869579.

Bastiansyah, Eko. (2012). Panduan Lengkap Membaca Hasil Tes Kesehatan. Penebar Plus, Jakarta: Penebar Plus

Corwin, E.Z. (2010). Buku saku patofisiologi. Terj. Dari Handbook of pathophysiology oleh Brahm, U. Penerbit Buku Kedokteran EGC, edisi revisi ke 3 Jakarta

Gani, G., Fatima, T., Qadri, T., Beenish, Jan, N., Bashir, O. (2018). Phytochemistry and Pharmacological Activities of Fig (Ficus carica) : A review. International Journal of Research in Pharmacy and Pharmaceutical Sciences, 3(2) : 80-82.

Harborne JB. (1987). Metode Fitokimia: Penuntun Cara Modern Menganalisis Tumbuhan. Padmawinata K, Sudiro I, penerjemah, Bandung, Penerbit ITB, Terjemahan dari: Phytohemical Methods.

Kakran M, Sahoo NG, Li L. (2011). Dissolution enhancement of quercetin through nanofabrication, complexation, and solid dispersion. Colloids Surf B Biointerfaces, 88(1): 121-130. https://doi.org/10.1016/j.colsurfb.2011.06.020

Katzung, Bertram G (2010) Farmakologi Dasar dan Klinik (terjemahan), Ed.10, Penerbit Buku Kedokteran EGC, Jakarta.

Krishna MG, Pallavi E, Ravi KB, et al. (2007). Hepatoprotective activity of Ficus carica Linn. leaf extract against carbon tetrachloride-induced hepatotoxicity in rats. DARU 15:162-7

Marliana, D.S., Venty, S., dan Suyono. (2005). Skrining Fitokimia dan Analisis Kromatografi Lapis Tipis Komponen Kimia Buah Labu Siam (Sechium edule Jacq. Swartz.) dalam Ekstrak Etanol. Jurnal Biofarmasi. 3(1): 29.

Mawa, S., Husain, K., dan Jantan, I. (2013). Ficus carica L. (Moraceae): Phytochemistry, Traditional Uses and Biological Activities, Hindawi Publishing Corporation Evidence-Based Complementary and SGP Ternative Medicine. Review Article Vol. 2013. https://doi.org/10.1155/2013/974256 
Podolsky, D.K \& Isselbacher, K.J. (2002). Tes Diagnostik pada Penyakit Hati. Dalam: Harisson Prinsip - Prinsip Ilmu Penyakit Dalam. Edisi 13. Penerbit Buku Kedokteran EGC. Jakarta.

Roy CK dan Das AK. (2010) Comparative evaluation of different extracts of leaves of Psidium guajava L.. for hepatoprotective activity. Pak J Pharm 23(1):15- 20.

Sahoo NG, Kakran M, Shaal LA, Li L, Müller RH, Pal M, Tan LP. (2011). Preparation and characterization of quercetin nanocrystals. $J$ Pharm Sci, 100(6): 2379-2390. https://doi.org/10.1002/jps.22446

Sawi., and Sleem A.A. (2010). Flavonoids and Hepatoprotective Activity of Leaves of Senna Surattensis (Burm.f.) In CCl4 Induced Hepatoxicity In Rats. Australian Journal of Basic and Applied Scrences. 4 (6): 1326-1333

Shamkant B. Badgujar, Vainav V. Patel, Atmaram H. Bandivdekar \& Raghunath T. Mahajan (2014) Traditional uses, phytochemistry and pharmacology of Ficus carica: A review, PharmaceuticalBiology, 52:11, 1487-1503, https://doi.org/10.3109/13880209.2014.892515

Vaya, J. Mahmood S. (2006). Flavonoid content in leaf extracts of the fig (Ficus carica L.), carob (Ceratonia siliqua L.) and pistachio (Pistacia lenticus L.). Biofactors 28 : 169-175. https://doi.org/10.1002/biof.5520280303

Wardah, Jola Rahmahani and Tatang Sopandi. (2016). Egg Cholesterol and Immunity of Quail (Coturnix coturnix japonica) Diet Phillanthus buxifolius Leaves as Feed Supplement. Asian Journal of Agricultural Research, 10: 114-125. https://dx.doi.org/10.3923/ajar.2016.114.125 